\title{
Retail Brand Building Through Promotional Communication: A Study That Focuses on Category Killers Promotional Flyers
}

\author{
Roberto Manzano Antón, Magdalena Ferrán Aranaz, María Puelles Gallo, Miguel Llorens Marin \\ Universidad Complutense de Madrid, Madrid, Spain
}

\begin{abstract}
Strong competition in retail distribution and the development of new purchasing options for the consumer generate a growing need to strengthen the retailers' brand image using all the communication elements, with promotional flyers being one of the most important ways to do this. Promotional flyers make-up $5.1 \%$ of the money spent on communication and rank third place in terms of importance for retailers. The aim of this investigation work is to focus on analysing the utility of a promotional tool, such as a flyer, to fulfil a strategic objective, like creating a retail brand image, within a modern dynamic sector that is growing fast, such as Category Killers. Two sources of information have been used to carry out the research. On the one hand, a survey conducted on those responsible for the definition and execution of the promotional plan, and on the other hand, the accumulation and analysis of all the flyers issued into the market thought-out a year by those retailers which belong to this format, in order to conduct a study of seven defined image indicators. This information has been largely analyzed using multidimensional scaling method and chi-square test. As a result, we have managed to gather the differential elements in flyers execution between those retailers that prize the communications of image attributes and those retailers which concentrate on communicating price. The first group makes greater use of promotional theme related flyers, and shows greater differentiation in both product assortment and the depth of the range being communicated.
\end{abstract}

Keywords: retail image, integrated communication, store promotional flyers

\section{Introduction}

Distribution undergoes a process of constant change within its competitive environment, which translates into, amongst other things, the convergence of commercial formats in the same place, as well as, strong competition between them in order to offer a commercial proposal that better meets the needs of the consumer. Due to the previous, the reinforcing of retail brand image through all the communication elements becomes increasingly important, with promotional flyers being one of the most powerful and used media.

This paper focuses on analysing the utility of promotional tools, such as a flyer, to fulfil a strategic objective,

Roberto Manzano Antón, Ph.D., Facultad de Ciencias Económicas y Empresariales, Campus de Somosaguas, Universidad Complutense de Madrid.

Magdalena Ferrán Aranaz, Ph.D., School of Statistics, Universidad Complutense de Madrid.

María Puelles Gallo, Ph.D., Facultad de Ciencias Económicas y Empresariales, Campus de Somosaguas. Universidad Complutense de Madrid.

Miguel Llorens Marin, Ph.D., Facultad de Ciencias Económicas y Empresariales, Campus de Somosaguas. Universidad Complutense de Madrid. 
like creating a brand image, within a modern, dynamic sector that is growing fast, like category killers.

Its aim is to analyze both the objectives set out by these flyers and the different ways in which retailers define their formal elements, in order to assess whether or not different groups of retailers can be established. We are interested in answering the following research questions:

(1) Which are the main communication objectives that the distribution of promotional flyers to consumers seek to accomplish?

(2) Which are the differential formal elements in flyer execution among the different groups of retailers created based on the communication objectives they pursue?

Its importance becomes apparent for three reasons. Firstly, the growing importance of the Category Killers format (non food big boxes stores), both in sectors where they compete and the market share they have had over them (Cetelem, 2008), and the commercial dynamism and innovation they develop to compete (Puelles, 2004).

Secondly, the functions the retail brand covers as an attraction and differentiation element in intratype competition formats (Sainz de Vicuña, 2001), and the critical priority for the distributor in making the retail brand a consumer trademark (AC Nielsen, 2005).

Lastly, the increase in promotional activity and flyers as a means of communications, maks up $5.1 \%$ of total budget spent on communication (Infoadex, 2008), and the fact is that it has been ranked by retailers the 3rd most important communication tool (Warnaby, Bennison, \& Davies, 2005).

\section{Theoretical Background}

Category killers are mainly characterised by their specialisation within a category of products (Diez de Castro, 2004), the key to this format being the crux associated with the development of the product assortment (McGoldrick, 2002; Puelles, 2006).

Martineau (1958) was the first author to expand the concept of brand image to the distribution field, and his application has become widespread ever since. As with products, consumers create their own images of retailers (Mazursky \& Jacoby, 1986). This image is strengthened through intermittent contact and experiences with the store (Kunkel \& Berry,1968) and ties in with the key elements of consumer behaviour, i.e., choosing the point of sale, the level of satisfaction received, or brand loyalty (Hartman \& Spiro, 2005). As with products, the perception of those qualities associated with a brand can be strengthened through favourable, strong and singular components associated with these (Keller, 1993). The evaluation of the components that make up the image will be determined by the different formats and its positioning, which reinforces the need to find a differential and attractive positioning by the retailer (Aliwadi \& Keller, 2004).

Integrated communication is understood as the coordination of all the means of communication within a company in order to transmit a comprehensive and consistent message, which is gradually moving towards considering all the communication typologies, be tactical or strategic, and the inclusion of all the target audience contact elements (Duncan \& Moriarty, 1998). A lack of consistency between the qualities being communicated and the brand image would weaken it and imply greater investment in communication (Keller, 1993).

With regards to promotions, the problem lies in when and to what level they should be integrated into the retailer's global communication objectives. For many experts, a retailer should develop its communication 
strategy with the intention of reflecting their positioning and differentiating the brand from its competitors (Sainz de Vicuña, 2001).

For Burton (1999), the key purpose of promotional flyers is to channel consumer purchasing, although there are others associated with the use of promotions as a communication tool. Gijsbrechts (2003) focuses on the analysis of flyers with regards to the size and value of the promotions, the categories included, and the criteria of the brand presence. Volle (1997) explains the elements that make up the promotional strength valuing a flyer for its visual and written elements so as to focus on the qualities being communicated. The promotional strength would depend on the number and type of products included, the promotions used and the difference between promotional and standard prices.

The research into flyers as a retail brand image communication tool is not common in literature. As a piece of communications, a flyer may be analyzed through its linguistic components, the photographs it includes and the figures design in order to evaluate the connection between the benefits it gives and the retail brand values. This analysis can be carried out on both the functional elements being transmitted about the retailer, and the symbolism of its communication structure (Arnold, Kuzinets, \& Handelman, 2001).

\section{Research Method}

The research method is based on two sources of information. Firstly, a survey is carried out via email amongst all those main responsible for the definition and development of the promotional activity within the defined format (mainly Marketing Directors). It is sent through to the entire population and 19 replies are received, which represents $76 \%$ of the defined population and $75 \%$ of the total points of sales.

The link between the objectives pursued through the use of flyers is ranked through a 5 levels Likert scale, using the variables detailed in Table 1.

Table 1

Objectives Evaluated by Those Responsible for Flyer Definition: Variables Analyzed

\begin{tabular}{|l|l|}
\hline Increase the volume of sales & Communicate the wide variety of assortment \\
\hline Build customer loyalty & Communicate the depth of the assortment \\
\hline Increase the number of buyers & Communicate the services available \\
\hline Attract new customers into the store & Communicate salespeople availability \\
\hline Increase the customers minimum spend & Improve brand recognition \\
\hline Improve the image of low price products & Improve retail positioning among competition \\
\hline Improve the image of good quality-price ratio & Strengthen the brand image \\
\hline Improve assortment knowledge & Improve brand awareness \\
\hline
\end{tabular}

The second information source includes a fortnightly collection of all the promotional flyers issued by the brands under observation, throughout a whole year, classifying and analysing a total of 225 flyers. As a result, we have two sources of information for each brand, the survey and all the flyers issued. A total of seven study indicators have been defined, which relate to the retailer brand image construction, in order to evaluate the behaviour of the different retailers with regards to each indicator.

The indicators developed are the following:

(1) Typology of flyer: Distinguishing between traffic flyers and thematic flyers, according to targeted 
customer (Chetochine, 1994) and the categories that make it up (Volle, 2001);

(2) Use of logo: Ties in with the recognition objectives of the logo to transmit a particular image (Stafford, Tripp, \& Bienstock, 2004), reinforced by the strength and frequency of its exposure (Henderson \& Cote, 1998);

(3) Heading: Choosing a heading is linked to the reasons that justify the promotion, which in turn affects consumer perception (Fraccastoro, Burton, \& Biswas, 1993). According to Gilbert (2003), the initial effect a promotion has on the brand image relates to its communication. One relevant factor, is the use of price, as the association of ideas this generates for the consumer is low (Yoo, Donthu, \& Lee, 2000), whereas options that focus on more hedonistic elements generate greater associations (Chandon, Wansink, \& Laurent, 2000);

(4) Use of services: Stems from the idea that services are a key element in the set-up of a retailer brand image (Keller, 1993) and its differentiation (Pappu, 2006; Ailawadi \& Keller, 2004);

(5) Product assortment elements that strengthen the retailer's competitive differentiation: The product mix is the main factor in generating the different positioning of retailers (Ailawadi \& Keller, 2004). The importance of the differentiation generated by both the distributor's brand (Puelles \& Puelles, 2003), and exclusive products, is picked up, as it is the focus when introducing new products;

(6) Product assortment elements that strengthen the depth: The retailer's image is affected by consumer perceptions of the benefits that the variety of purchasing options provides (Kahn \& Wansink, 2004);

(7) Distribution of space between product (photo/text) and price communication.

The multidimensional scaling method has been used to analyze the sources of information, with the aim of exposing the similarities between the different objects. The result is the creation of three aggregated indexes. Two of them refer to the questionnaires received (one reflects the objectives proposed and the other the importance of the different elements included within the flyers), and the third, refers to retail groups, and how closely they tie in with the previous indicators.

Lastly, we applied a chi-square test to find out whether there are retailer groups with different behaviour patterns regarding the indicators developed.

Table 2

Evaluation of the Aggregated Index Variables (Ranking)

\begin{tabular}{lrcl}
\hline Aggregated index & Mean & Median & Standard deviation \\
\hline Sales & 12.17 & 13.00 & 2.21 \\
Price & 8.79 & 9.25 & 3.23 \\
Image & 8.41 & 9.12 & 2.98 \\
Image attributes & 6.90 & 7.00 & 1.76 \\
\hline
\end{tabular}

\section{Hypothesis Definition and Major Results}

\section{Questionnaire-Related Results}

Using the multidimensional scaling method, we have established four aggregated indexes that refer to flyer objectives. The headings defined are: sales, price, image and attributes (see Figure 1).

The evaluation given by retailers for the variables that each index includes enables us to draw the following conclusions:

(1) The main role of flyers is to generate sales figures by attracting new customers into the store, which in 
turn means more shoppers. This role exceeds that of other variables such as loyalty and increased spending;

(2) This objective is achieved through a low-price image;

(3) The elements which relate to product assortment, in any of its components, are secondary objectives in flyer communication. This is also true for services and staff availability which is the least valued objectives;

(4) Retail brand loyalty is associated with both brand recognition and image, and assortment, services and salespeople. The aim of increasing customer spending, however, is particularly related to knowledge and variety of assortment, and to a less degree, the services available and the assortment depth.

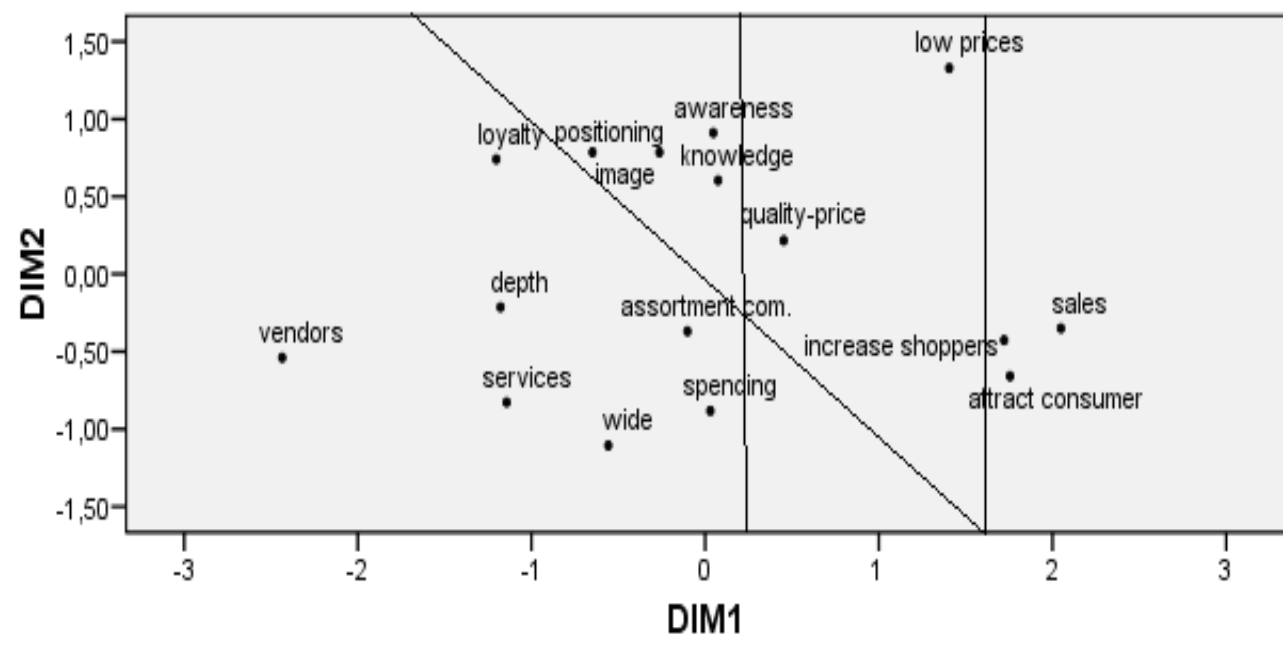

Figure 1. Multidimensional scaling method: Aggregated indexes referred to retail flyer objectives.

Secondly, we have established retail aggregated indexes that relate to the flyer objectives ones. Analysis shows that the dimensions referred to image attributes and price have the greatest discriminate capacity. The result therefore, is the ultimate creation of three retailers groups according to the importance they place on price and image attributes indexes (see Figure 2).

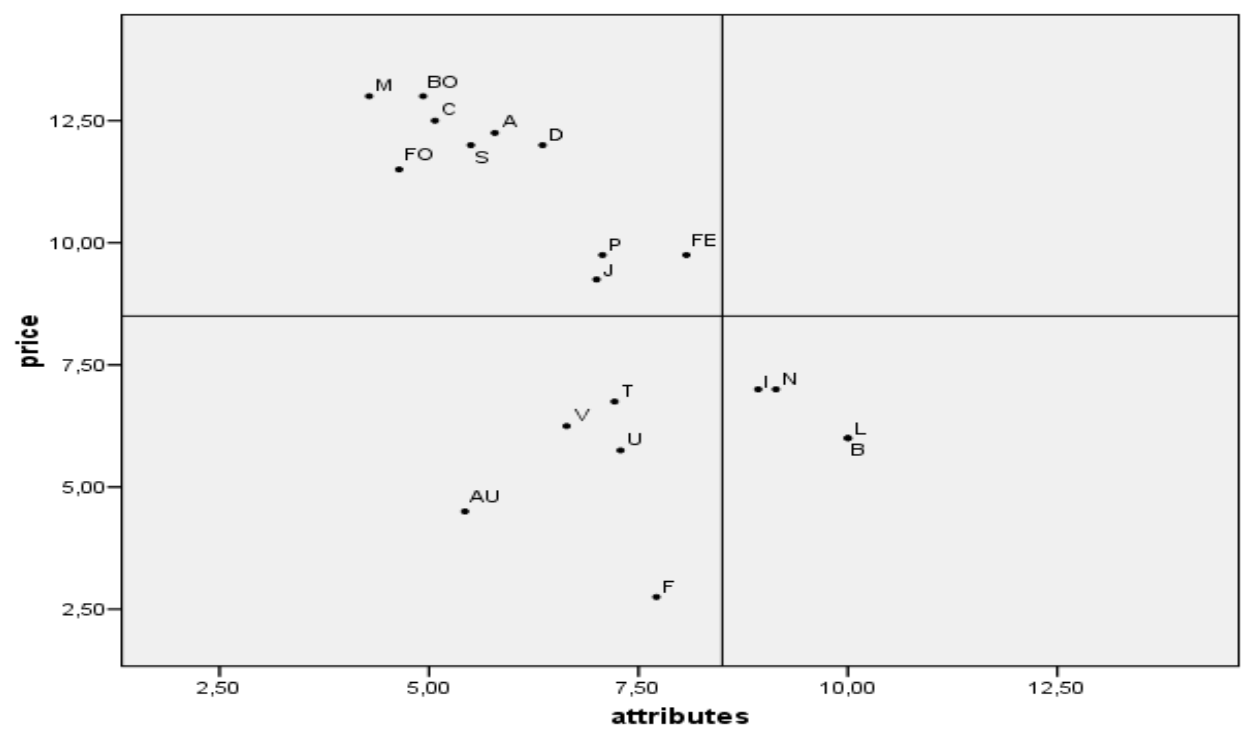

Figure 2. Multidimensional scaling method: Aggregated indexes referred to retailers. 
- High prices/Low image attributes: A group of retailers that aim to prioritise those variables related to prices within their flyers. This group is made up of seven retailers;

- Low price/High image attributes: A group that prioritizes the communication of retailers' brand attributes as the objective of their flyers. This group is made up of 4 retailers;

- Other retailers: Retailers without a clear preference between price and image attributes indexes. This group is made up of eight retailers.

\section{Hypothesis Defined}

Large and medium category killers use the formal elements of promotional flyers as a strategic tool in the creation of their retail brand associations. Though there is a relation between the development of the flyer formal elements and the different communication objectives of the retail brand. Retailers that prioritise the objectives of communicating attributes over price (see Figure 3):

H1: Create flyers that are predominantly of a thematic nature as opposed to traffic ones.

H2: Create flyers with greater logo presence.

H3: Create flyers with titles that predominantly refer to events, as opposed to titles which focus on price and offers.

H4: Create flyers that include a greater communication of services offered.

H5: Create flyers that show greater differentiation of assortment through own brands, exclusive products and communication of the new products.

H6: Create flyers that show greater depth of assortment.

H7: Create flyers with more space allocated to product communication, than to the communication of prices.

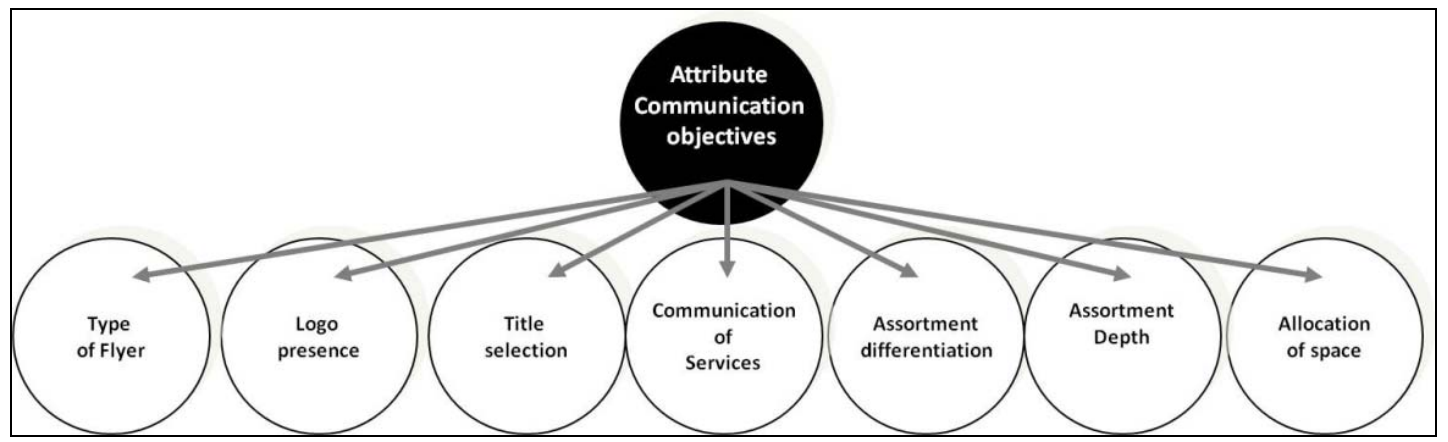

Figure 3. Considered variables.

\section{Results Related to the Analysis of Flyers for Each One of the Retailers' Aggregated Indexes}

The last phase of the research method applied, is an analysis of the distribution of frequencies of retailers for each group, using the Chi-square test, through the variables defined within each indicator, and where these distribution frequencies are different, evaluating their statistical importance (see Table 3). In order to apply the Chi-square test, the values of each variable have been grouped into two intervals with a cut-off mark. The three values which appear in the relevant row, are the percentages of retailers within each group, with a value below the cut off mark. The Chi-square test is used to verify whether the differences between the three percentages are statistically significant. The main conclusions are the following: 
Retailers that prize the communication of attributes as the objective of their promotional flyers focus heavily on the development of a thematic type flyer, as an alternative to those which focus exclusively on prices and offers. In addition, they use a greater number of pages to develop their promotions.

These retailers focus less on communicating the brand logo, both on the front page and on the coverage and space provided within the flyer.

They give greater coverage to the communication of services, be it in the average number of services per flyer or the total space included within the flyer, although the total percent given is similar to that of price focused retail groups.

The differentiation of the assortment is mainly centred round a greater presence of distributor brands, greater communication of exclusive products and significantly higher weight over the communication of new products.

With regards to assortment depth they communicate fewer categories per flyer when compared to the total number of categories they market. This fact, and the greater number of items on promotion, means a significantly higher communication of products per category than the group which focuses on price.

Table 3

Group Results per Indicator and Variable (\% of Retailers With a Value Below the Cut-off Mark)

\begin{tabular}{|c|c|c|c|c|c|}
\hline Indicator & Variable & $\begin{array}{l}\text { High } \\
\text { attribute/Low } \\
\text { price group } \\
(\%)\end{array}$ & $\begin{array}{l}\text { High price/Low } \\
\text { attribute group } \\
(\%)\end{array}$ & $\begin{array}{l}\text { Others group } \\
(\%)\end{array}$ & $\begin{array}{l}\text { Pearson's } \\
\text { Chi-squared }\end{array}$ \\
\hline \multirow[t]{2}{*}{ Typology of flyer } & Use of thematic type flyers (total \%) & 0.0 & 71.4 & 100.0 & $0.002 *$ \\
\hline & Number of average pages per flyer & 25.0 & 85.7 & 87.5 & $0.045^{*}$ \\
\hline \multirow[t]{3}{*}{ Use of logo } & Use of logo on the front page (\% of space) & 75.0 & 0.0 & 50.0 & $0.028 *$ \\
\hline & Logo coverage within the flyer (page \%) & 75.0 & 42.9 & 100.0 & $0.043 *$ \\
\hline & Space given to the logo (internal \%) & 50.0 & 85.7 & 100.0 & 0.081 \\
\hline \multirow[t]{2}{*}{ Flyer heading } & Headings centred on themes/events (\% flyer) & 50.0 & 14.3 & 62.5 & 0.158 \\
\hline & Headings centred on price/offers (\% flyer) & 75.0 & 28.6 & 50.0 & 0.326 \\
\hline \multirow[t]{3}{*}{ Use of services } & Number of services communicated (average) & 25.0 & 71.4 & 62.5 & 0.306 \\
\hline & Communication of sales staff (\% of flyers) & 100.0 & 100.0 & 100.0 & \\
\hline & Space given to services (\% space per flyer) & 50.0 & 57.1 & 50.0 & 0.956 \\
\hline \multirow{3}{*}{$\begin{array}{l}\text { Differentiation of } \\
\text { assortment }\end{array}$} & Distributor brand communication (\% flyer) & 25.0 & 100.0 & 75.0 & $0.025^{*}$ \\
\hline & Communication of exclusive prod (\% flyer) & 50.0 & 85.7 & 75.0 & 0.430 \\
\hline & Communication of new prod (\% flyer) & 25.0 & 100.0 & 75.0 & $0.025 *$ \\
\hline \multirow{3}{*}{$\begin{array}{l}\text { Depth of } \\
\text { assortment }\end{array}$} & Items communicated per flyer (average) & 0.0 & 85.7 & 75.0 & $0.012 *$ \\
\hline & Items per category(average No. of items) & 0.0 & 100.0 & 87.5 & $0.001 *$ \\
\hline & Categories communicated (\% vs. total Categ.) & 75.0 & 0.00 & 12.5 & $0.010 *$ \\
\hline Space distribute & Space given to product (\% vs. space) & 25.0 & 42.9 & 50.0 & 0.710 \\
\hline
\end{tabular}

Note. * Significant at $<0.05$ level.

Based on the previous, those retailers that prioritise objectives related to the communication of attributes in their promotional flyers when compared to the communication of prices show the following results by defined hypothesis (see Table 4). 
Table 4

Hypotheses and Their Results

H1: Create flyers predominantly of a thematic nature.

H2: Create flyers with greater logo presence.

Accepted

Rejected. Less use of the logo both on the front page and within. Less space allocated and less frequency of appearance.

H3: Create flyers with titles that predominantly refer to events.

Not statistically proven. Greater use of titles that relate to events.

H4: Create flyers that include greater communication of Not statistically proven. Greater number of services communicated. \begin{tabular}{l|l} 
services. & More space allocated. Communication of vendors. \\
\hline
\end{tabular}

H5: Create flyers that show a greater differentiation of Accepted. Higher use of distribution brands, exclusivities and assortment. communication of new products. \begin{tabular}{|l|l|}
\hline H6: Create flyers that show greater depth of assortment. & $\begin{array}{l}\text { Accepted. Higher products communicated by category and lower } \\
\text { number of categories communicated by flyer. }\end{array}$ \\
\hline
\end{tabular}

H7: Create flyers with more space allocated to product Not statistically proven. More global space given to visuals and text communication. when compared to space devoted to price.

\section{Implications}

The aim of this paper is to study the different promotional communications objectives pursued by those retailers that belong to the category killers format, and from there, examine how they come to be the promotional flyers distributed in the market.

The first factor which stands out is the small number of brands that clearly opt for the communication of image attributes as a priority over price focus. Only four of the nineteen brands analyzed prioritise this key aspect, both in their set objectives and as the priorities they consider when creating flyers. Another interesting factor is the large number of brands that do not have a clear proposal between the objectives of price and image attributes.

The main difference in behaviour between the groups is the actual type of flyer used with regards to the assortment offered. Those retailers that prioritise image attributes focus mainly on a smaller number of categories that show broader product depth with greater promotional offers. They also aim to offer a competitive difference through distribution brands communication, new products and to a less degree, through exclusive brands.

It is also interesting to highlight the greater use of communication focused on services offered, which in terms of total space given is almost four times greater than that spent by brands who focus on price. The communication of services offered should be gradually developed as an important differentiating factor.

The most relevant point would centre round the need to reinforce the attributes construction aspects for those brands that see this option as their key focal point, with the aim of strengthening its competitive difference in relation to those brands that concentrate heavily on price.

\section{References}

ACNielsen. (2005). The 14th Annual ACNielsen Survey of Trade Promotion Practices.

Ailawadi, K. L., \& Keller, K. L. (2004). Understanding retail branding: Conceptual insights and research priorities. Journal of Retailing, 80(4), 331-342.

Arnold, S. J., Kuzinets, R. V., \& Handelman, J. M. (2001). Hometown ideology and retailer legitimation: The institutional semiotics of Wal-Mart flyers. Journal of Retailing, 77(2), 243.

Burton, S. (1999). Exposure to sales flyers and increased purchases in retail supermarkets. Journal of Advertising Research, 39(5), $7-14$.

Cetelem. (2008). El Observador. Los nuevos consumidores españoles. Sus preferencias. Observador Cetelem.

Chandon, P., Wansink, B., \& Laurent, G. (2000). A benefit congruency framework of sales promotion effectiveness. Journal of Marketing, 64(4), 65-81.

Chetochine, G. (1994). Marketing estratégico de los canales de distribución, Ediciones Granica. Barcelona. 
Diez de Castro, E. (Coordinador). (2004). Distribución comercial (3rd ed.). McGraw Hill.

Duncan, T., \& Moriarty, S. E. (1998). A communication-based marketing model for managing relationships. Journal of Marketing, 62(2), 1-13.

Fraccastoro, K., Burton, S., \& Biswas, A. (1993). Effective use of advertisements promoting sale prices. Journal of Consumer Marketing, 10(1), 61.

Gijsbrechts, E., Campo, K., \& Goossens, T. (2003). The impact of store flyers on store traffic and store sales: A geomarketing approach. Journal of Retailing, 79(1), 1-16.

Gilbert, D. (2003). Retail marketing management. England: Prentice Hal.

Hartman, K. B., \& Spiro, R. L. (2005). Recapturing store image in customer-based store equity: A construct conceptualization. Journal of Business Research, 58(8), 1112-1120.

Henderson. P. W., \& Joseph, A. C. (1998). Guidelines for Selecting or modifying logos. Journal of Marketing, 14-30.

Infoadex. (2008). La inversión publicitaria en España 2008. Infoadex.

Kahn, B. E., \& Wansink, B. (2004). The influence of assortment structure on perceived variety and consumption quantities. Journal of Consumer Research, 30(4), 519-533.

Keller, K. L. (1993). Conceptualizing, measuring, managing customer-based brand equity. Journal of Marketing, 57(1), 1.

Kunkel, J. H., \& Berry, L. L. (1968). A behavioral conception of retail image. Journal of Marketing, 32(21).

Martineau, P. (1958). The personality of the retail store. HBR, 36(1), 47-55.

Mazursky, D., \& Jacoby, J. (1986). Exploring the development of store images. Journal of Retailing, 62(2), 145-165.

McGoldrick, P. (2002). Retail marketing (2nd ed.). Maidenhead: McGraw Hill.

Pappu, R., \& Quester, P. (2006). A consumer based method for retailer equity measurement: Results of an empirical study. Journal of Retailing and Consumer Services, 13, 316-329.

Puelles, M. (2004). Grandes especialistas no alimentarios: Análisis del fenómeno con especial referencia a la Comunidad Autónoma de Madrid. Ministerio de Industria, Turismo y Comercio.

Puelles, M. (2006, September-October). Competencia y nuevas estrategias en el sector de la distribución especializada no alimentaria. Revista Distribución y Consumo, 5-21.

Puelles, J. A., \& Puelles, M. (2003, May-June). Marcas del distribuidor; más de 30 años de un proceso dinámico, competitivo e imparable. Distribución y Consumo, 51-71.

Sainz de Vicuña, J. M. (2001). La distribución comercial: opciones estratégicas. Esic Editorial, Madrid, 402.

Stafford, M. R., Tripp, C., \& Bienstock, C. (2004). The influence of advertising logo characteristics on audience perceptions of a nonprofit theatrical organization. Journal of Current Issues \& Research in Advertising, 26, 37-45.

Volle, P. (1997). La perception de l'intensité promotionnelle des prospectus par les consummateurs: vers un modele conceptuel. 13 Congres de l'Association francaise du Marketing. Toulouse, Francia.

Volle, P. (2001). The short-term effect of store-level promotions on store choice, and the moderating role of individual variables. Journal of Business Research, 53(2), 63-73.

Warnaby, G., Bennison, D., \& Davies, B. J. (2005). Marketing communications in planned shopping centres: evidence from the UK. International Journal of Retail \& Distribution Management, 893.

Yoo, B. D. N., Donthu, N., \& Lee, S. (2000). An examination of selected marketing mix elements and brand equity. Journal of Academic of Marketing Science, 28(2). 